\title{
An interview with Hunt Emerson
}

\author{
Francisco Saez de Adana
}

Instituto Franklin, Universidad de Alcalá

kiko.saez@uah.es

\section{(c) (i)}

\section{Resumen}

Este artículo presenta una entrevista a Hunt Emerson acerca de su proceso de adaptación del Infierno de Dante, la primera sección de La Divina Comedia. Emerson cuenta su aproximación a la obra y su visión sobre la misma a la hora de transformar el poema original en una historia cómica.

Palabras clave: Hunt Emerson; Infierno de Dante; Kevin Jackson; adaptación; comic humorístico.

\section{Abstract}

This paper presents an interview with Hunt Emerson about his adaptation process of Dante's Inferno, the first section of The Divine Comedy. Emerson tells his approach to Dante's work and his vision of it when transforming the original poem into a comic story.

Keywords: Hunt Emerson; Dante's Inferno; Kevin Jackson; adaptation; humour comics. 
$\mathrm{H}$ unt Emerson is a British humorous cartoonist whose career started in the early I970s. He was closely involved with the Birmingham Arts Lab of the mid-to-late I970s, and with the British underground comics scene of the I970s and I980s. His earliest strips in the I970s appeared in British small press comics and in the I980s he started working with several US underground and independent publishers. Since then, he has worked with some different publishers both in the US and the UK as Eclipse, DC Comics or Knockabout Comics among others. Some of his most important works include Alan Rabbit, Calculus Cat, Max Zillion \& Alto Ego, Pusspuss, Momo and Fuzi, Charlie Chirp, plus the one-shot stories "Cakes And Bricks," "The Dentist," and "Mouth City". He has also worked in books as You Are Maggie Thatcher (scripted by Pat Mills) and Outrageous Tales From the Old Testament in which he tackled a version of the Book of Leviticus written by Alan Moore. His work includes series from all the range of ages, from the stories addressed to a younger audience as Little Plum and Ratz included in the famous British magazine, The Beano to his adult feature Firkin the Cat, strip that has run in the soft-porn magazine Fiesta since 198I. He has obtained many awards including the UK's Strip Cartoonist of the Year, as was chosen as one of 75 Masters of European Comics by the Centre National de la Bande Dessinée et de L'Image in France.

He has also drawn some irreverent adaptations of classics from the literature as Lady Chatterley's Lover, The Rime of the Ancient Mariner and the life of Casanova in Casanova's Last Stand. He has collaborated with Kevin Jackson on comic books dealing with the ideas of I 9 th century artist, writer, critic and political theorist John Ruskin. This collaboration is the seed for the adaptation of Emerson's cartoon version of Inferno, the first section of Dante's poem La Divina Commedia. Emerson's Inferno is, in the words of Kevin Jackson, "a series of devilishly funny jokes, which are even richer and funnier if you know something about the work that inspired it." I Therefore, Emerson with Jackson's counsel transforms Dante's poem in "a hair-raising adventure, an astonishing if sometimes repulsive chamber of horrors, a chain of vivid and unforgettable character sketches" ${ }^{2}$ without losing the humorous approach that is the mark of Emerson's comics. However, he manages to mix his ability to create a continuous number of jokes, some of them which are in the limit of the bad taste with a story which stays very close to the story-line and characters of the poem. Hunt Emerson's, therefore, stands as one of the most interesting adaptation of Dante's work to the comics, mainly due to his intelligent mixture of the humorous approach of his author and the fidelity with which he adapts the Dantescan source.

I. Kevin Jackson. "A New Map of Hell” in Hunt Emerson's Dante's Inferno. London: Knockabout, 20I2, p. 76 .

2. Ibid. 

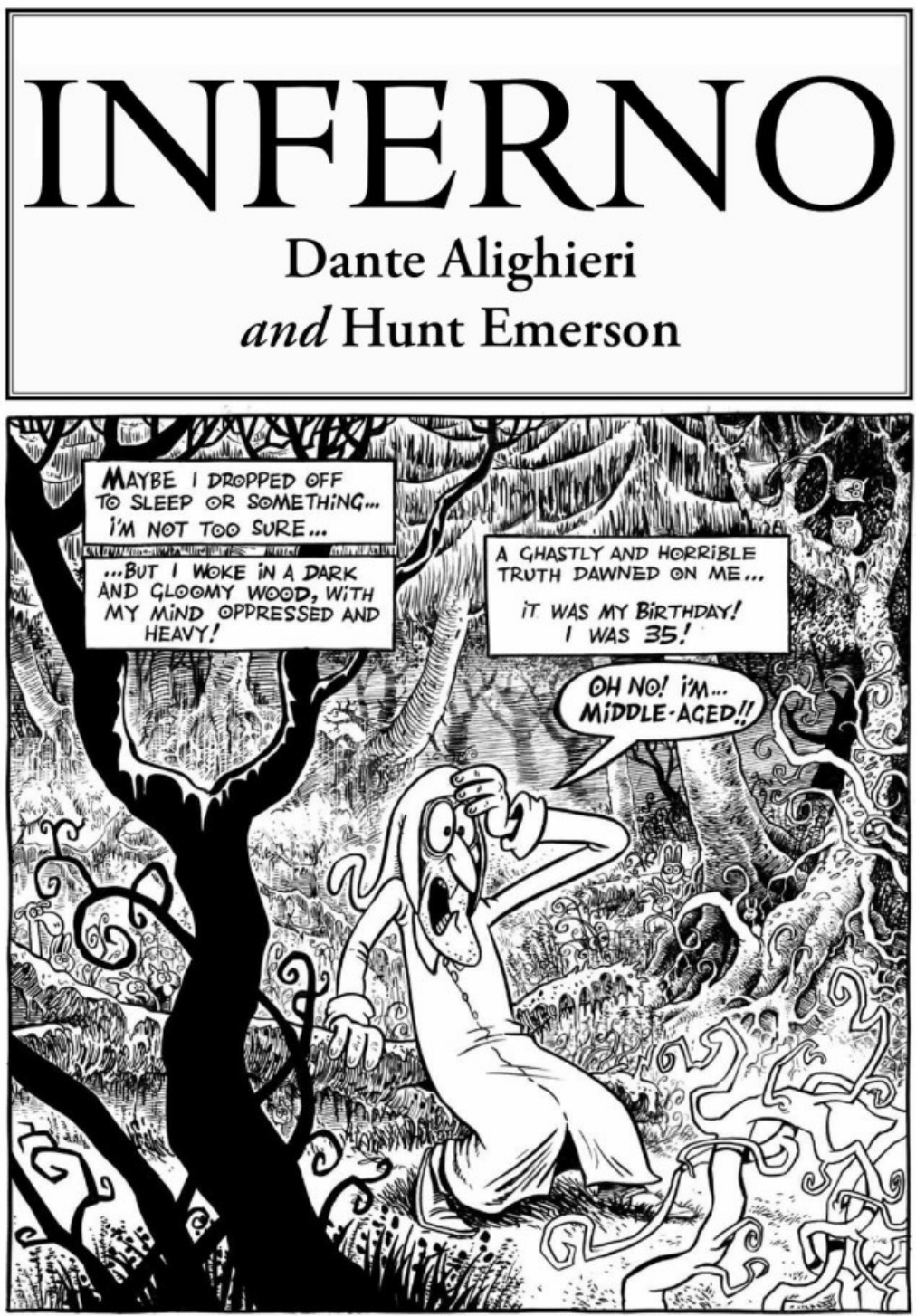

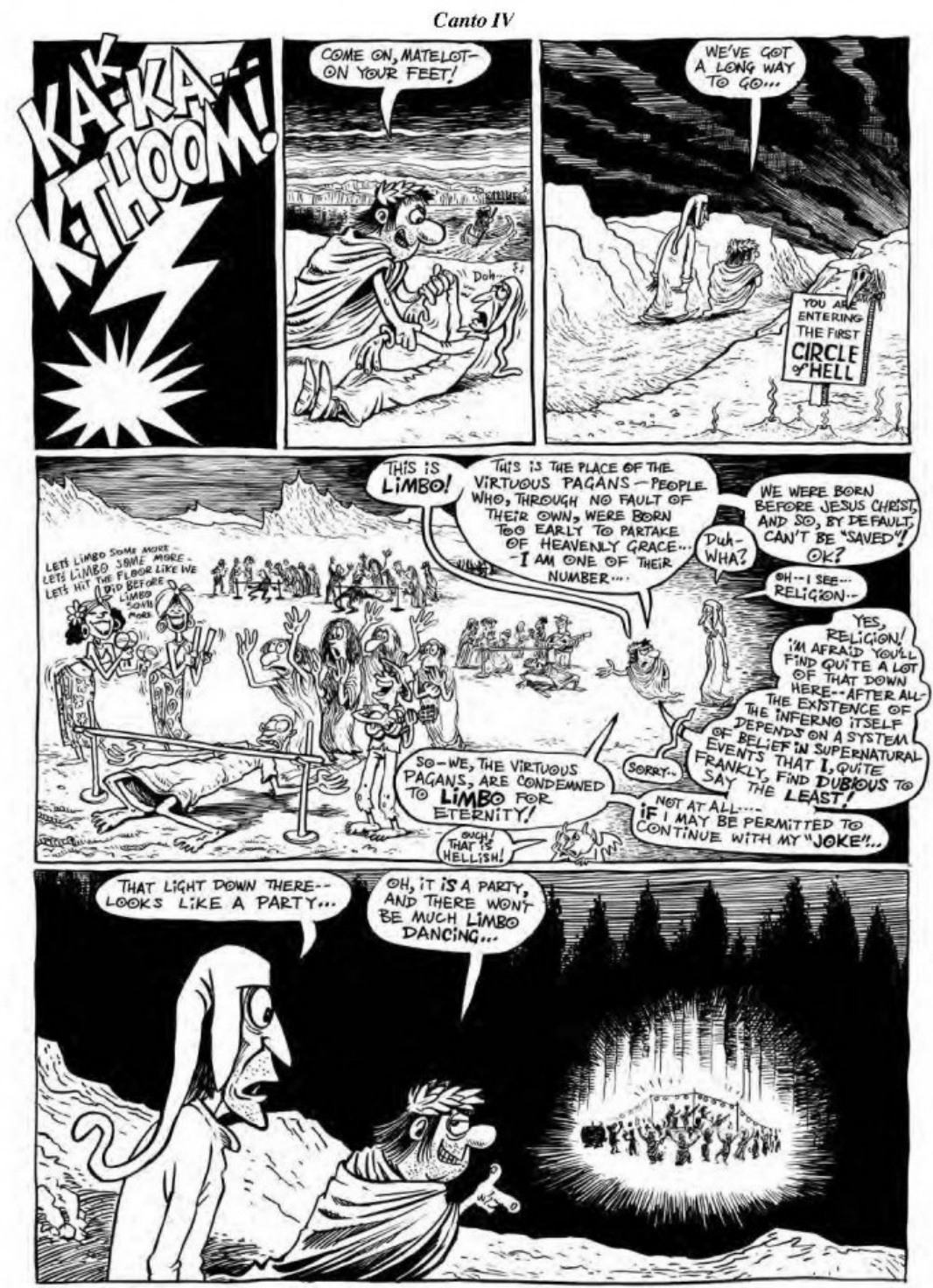
In this interview, Emerson talks about his vision of Dante and the process of adaptation he followed.

F.S.: How do you feel relevant Dante nowadays? Is there any relationship with our current society?

H.E.: The Divine Comedy will always be one of the essentials of Western culture, even if it is not very contemporary in its makeup. There are a number of modern (mainly) political figures I would like to see headfirst in a flaming pit.

F.S.: How do you adapt Dante for today's audiences? Are there any influences from other comics authors when you adapt Dante?

H.E.: When I set about doing a comic book version of a classic, I always look for high drama, and spiritual or philosophical seriousness, in order to make them funny. I don't look for subjects that are already comedies, as that would mean I was only illustrating someone else's jokes or satire. I like to weave humour around the seriousness of the original. So, in my comics, the characters are always serious about their part in the narrative. But they are also aware that they are characters in a comic book. And, comics being a non-serious medium, they are not very good actors in the narrative, and they stumble and misinterpret things in a naïve and stupid way. They are not paid enough to be good! One of the major influences on my love of comics as a child (an influence which I share with Kevin Jackson) was MAD magazine, particularly the work of Harvey Kurtzman, Wally Wood, Jack Davies and Bill Elder. They took other items of culture - movies, TV, advertising, literature, other comics - and made hilarious, detailed comic strips of them. I loved them! So, my Dante was going to have that MAD flavour - a very serious drama performed by buffoons. Then, the comic relationship between Dante and Virgil became an important element. They were like comedy theatre and music hall, like Laurel and Hardy. Having two characters is always a good plan in comedy - throughout the horrors of the Underworld, the pair are bickering and quarrelling; bad actors, aware that they're in a comic book.

F.S.: And from outside the world of comics?

H.E.: While working on Inferno I examined Gustave Doré, of course, but I also looked at any and every other version I could find. They did not influence my version, apart from Doré. I learned from him how to draw the rocks and landscape of hell. Early in our collaboration on Inferno I visited Kevin Jackson at his home in Cambridge. He had collected from his bookcase about 35 illustrated versions of Dante, including Botticelli, Tom Phillips, and many more, for me to examine. After that, Kevin kept me supplied with notes and criticism, with diagrams of Dante's underworld, 
and with suggestions for details that we should include. Then he wrote the excellent essay on Inferno that follows the comic, all of which made our version a reasonably faithful and accurate telling of the story. We excluded most of the I4th century Florentine and Roman political gossip and satire, and we decided some things were not relevant today (such as Dante's inclusion of the Prophet), but we like to think that if a student had to write an essay on Inferno, they could use our version as a crib.

F.S.: What are the features of comics which help adapting Dante or other classics? Do you think that the language of comics is suitable for the adaptation of this kind of works?

H.E.: For me, comics are always humorous. I don't do "serious" comics, I like my readers to have fun. So, if I take serious classic literary material and present it as a comic, it is always going to be a comedy version. The form of Comics has a unique structure that lets it laugh at itself, while still presenting classical, serious literature.

F.S.: Which choices have you made when representing Inferno graphically?

H.E.: As soon as I had a comedy partnership - Dante and Virgil - I had to find out how they looked. Virgil is usually depicted as a noble, tall figure, so I decided he should be played by Danny DeVito. A grumpy, British DeVito. There are many pictures of Dante. I have two of them on my wall. I think he had bad teeth, and suffered from toothache, which could explain why he was so angry! I made my Dante a cartoon version of the real man. The rest of the Underworld is inhabited by people who are just doing their job - they are actors in a comic book, and they usually know this. They mostly get on with what they have to do, and will try and avoid problems and work if they can. We held a launch party for the book at the very high class Italian Cultural Embassy in London. Kevin and I dressed as the Dynamic Duo. Many other guests dressed as Demons, and by the end of the evening, the very nice lady who was the Italian Cultural Ambassador was wearing horns.

F.S.: Describe the process of collaboration with a writer when you adapt Dante.

H.E.: Kevin Jackson is a writer, film maker and broadcaster. He suggested that we should make Inferno a comic. This coincided with the same suggestion from another writer friend of mine, Ross Gilfillan, and the combined opinions of these people whom I respect made me think it would work. I visited Kevin at his home in Cambridge to discuss the project, and he had 35 illustrated editions of Dante laid out for me to view. We talked into the night and I saw the magic of Dante, and how it could be subverted into a comic. At first, Kevin was going to write the dialogue for the comic, but as soon as I began drawing the characters I realised I wanted to write it 
myself. So Kevin provided me with a detailed working version of the story, and I worked from 2007 until 2012 to draw the book. Kevin also provided much comment and suggestion, backed up with reference material, so the creative process was very mixed.

F.S.: If you think that there is anything else relevant to say, please add it to this interview.

H.E.: I think I have probably said enough! Except that I think our version of Dante's Inferno is the best comic book I have done!

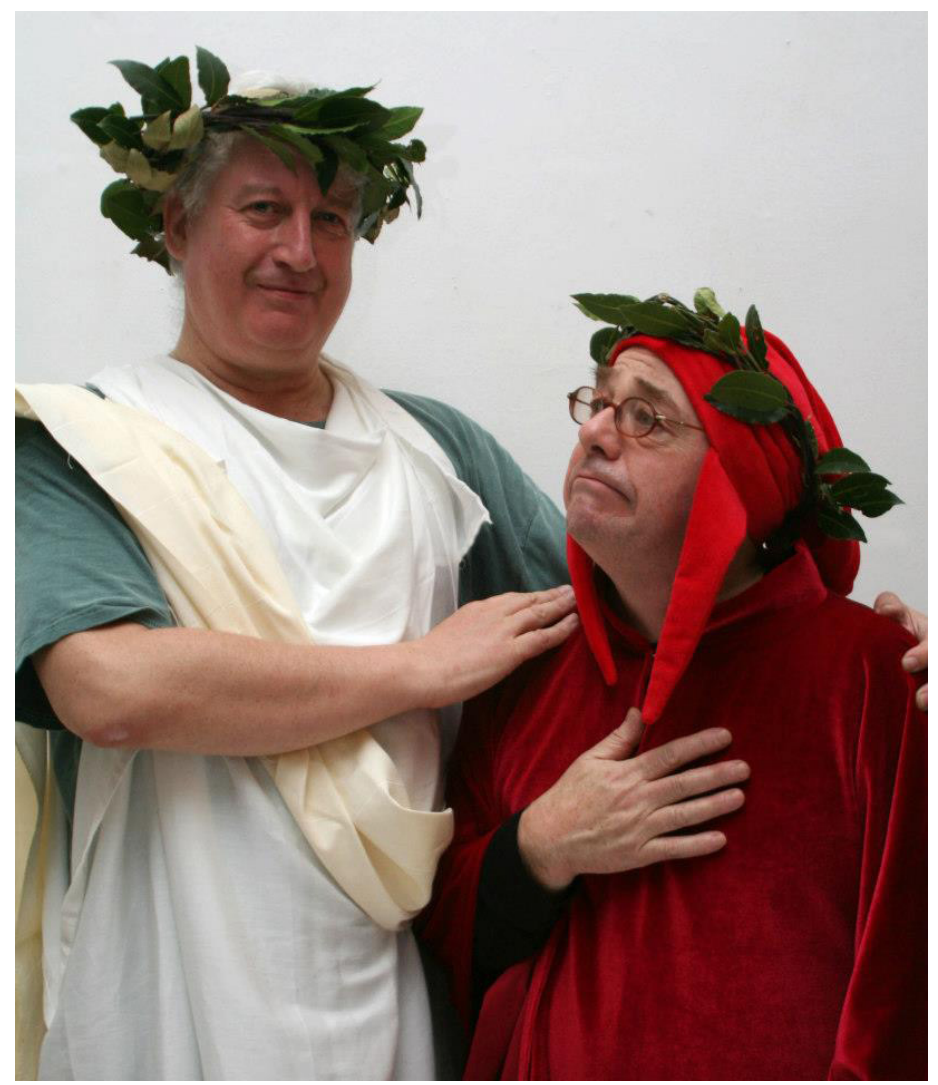


